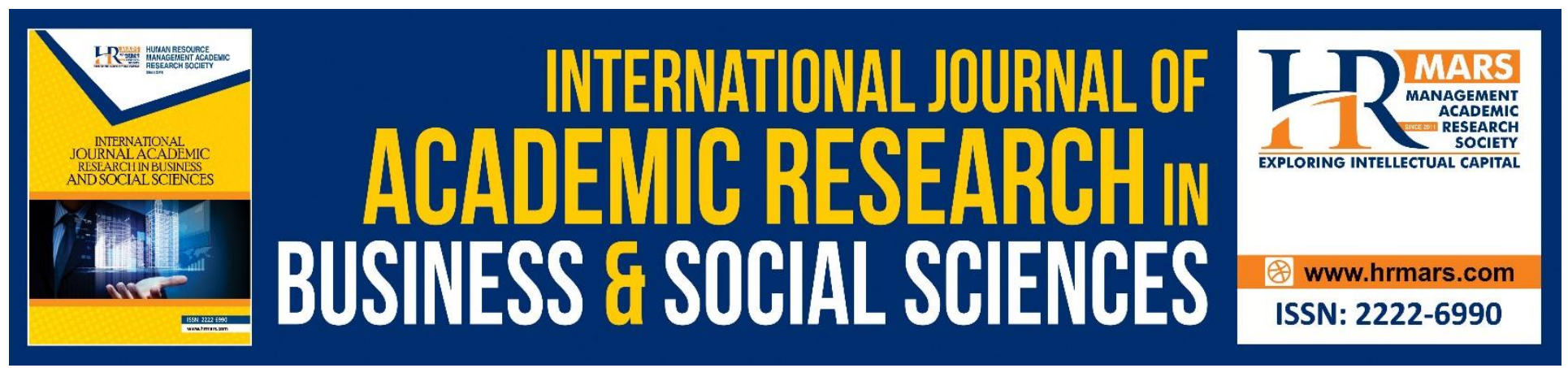

\title{
Organizational Citizenship Behaviour and Turnover Intention among Generation $Y$ in Malaysia
}

Ong Shze Yin, Ong Choon Hee, Rahamah Mahmood, Mohd Syafiq Hanis Hamli

To Link this Article: http://dx.doi.org/10.6007/IJARBSS/v8-i7/4412

DOI: $\quad 10.6007 /$ IJARBSS/v8-i7/4412

Received: 20 May 2018, Revised: 21 June 2018, Accepted: 29 June 2018

Published Online: 23 July 2018

In-Text Citation: (Yin, Hee, Mahmood, \& Hamli, 2018)

To Cite this Article: Yin, O. S., Hee, O. C., Mahmood, R., \& Hamli, M. S. H. (2018). Organizational Citizenship Behaviour and Turnover Intention among Generation $\mathrm{Y}$ in Malaysia. International Journal of Academic Research in Business and Social Sciences, 8(7), 690-701.

\section{Copyright: (C) 2018 The Author(s)}

Published by Human Resource Management Academic Research Society (www.hrmars.com)

This article is published under the Creative Commons Attribution (CC BY 4.0) license. Anyone may reproduce, distribute, translate and create derivative works of this article (for both commercial and non-commercial purposes), subject to full attribution to the original publication and authors. The full terms of this license may be seen

at: http://creativecommons.org/licences/by/4.0/legalcode

Vol. 8, No. 7, July 2018, Pg. 690 - 701

http://hrmars.com/index.php/pages/detail/IJARBSS

JOURNAL HOMEPAGE

Full Terms \& Conditions of access and use can be found at http://hrmars.com/index.php/pages/detail/publication-ethics 


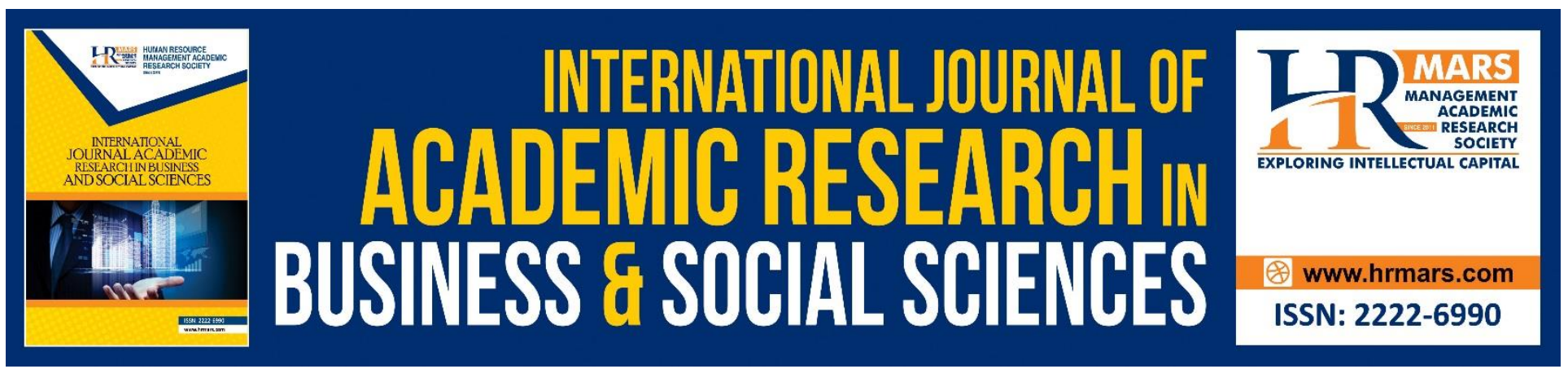

\title{
Organizational Citizenship Behaviour and Turnover Intention among Generation $Y$ in Malaysia
}

\section{Ong Shze Yin, Ong Choon Hee, Rahamah Mahmood, Mohd Syafiq Hanis Hamli}

Azman Hashim International Business School, Universiti Teknologi Malaysia, Johor, Malaysia.

Email: sying_shzeyin@hotmail.my

\begin{abstract}
The purpose of this study is to investigate the relationship between Organizational Citizenship Behaviour (OCB) of generation $Y$ and their turnover intention in Malaysia. Organizational Citizenship Behaviour (OCB) was referred to Altruism, Conscientiousness, Courtesy, Sportsmanship and Civic Virtue whereas turnover intention was defined as the intention of generation $Y$ to leave their workplace. A quantitative cross-sectional survey approach was deployed in this study along with factor analysis, correlation analysis and multiple regression analysis in analysing the data collected. The findings of the study revealed that the dimension of Altruism is negatively related to the turnover intention. The outcomes of this research could facilitate employers to identify employees based on their OCB to nurture and retain talents in the organization and subsequently reduce their turnover intention.
\end{abstract}

Keywords: Organizational Citizenship Behaviour (OCB), Turnover Intention, Altruism, Conscientiousness, Courtesy, Sportsmanship, Civic Virtue.

\section{Introduction}

In the current workplace, most of the positions were dominant by generation Y. It has been a norm that most of the employees tend to leave their jobs owing to failing to find suitable jobs that fit their needs. Most of the employees who left their jobs were dominated by generation $\mathrm{Y}$. Through the evaluation of $\mathrm{HR}$ practitioners, it is proven that the high turnover rates mostly come from generation $Y$ and it has become a concerning issue for most of the industries and organizations (Yamazakia \& Petchdee, 2015). HR has to continuously search for suitable candidates to best fit the vacancies, this would require much of time and increase in operational cost as recruitment may be time consuming and it would not guarantee that the candidates who came for interview will suit the company requirements. Extra effort is needed in searching for suitable candidates to join the workforce to ensure that the hired employees will stay long in the organization. In the current scenario, industries are facing a critical manpower shortage phenomenon that leads to incompletion of project. According to Collin (2015), it was stated that Malaysia was suffering from employees' turnover rate of $13.2 \%$ in year 2014 and remained a static increase in year 2015 to $14.3 \%$ where manufacturing 
INTERNATIONAL JOURNAL OF ACADEMIC RESEARCH IN BUSINESS AND SOCIAL SCIENCES Vol. 8, No. 7, July 2018, E-ISSN: 2222-6990 @ 2018 HRMARS

industries were having the most staff turnover rate. It is understood that high turnover rate will result in low productivity and increase organization's operation cost. Hence, it has become a concerning factor that most organizations have failed to retain their own employees. In such cases, organizations have to re-evaluate their organization's operational approach and introduce organizational citizenship behaviour (OCB) in the workplace. OCB has been proven to be one of the factors that effectively decreases the turnover rate of the employees in an organization. In the concept of OCB, it is believed that employees shall be fostered with commitment towards the organization and at the same time influencing others in committing towards their work and organization. OCB consists of elements such as altruism, conscientiousness, courtesy, sportsmanship and civic virtue. Each element serves as contributing factors for the employees to be committed on their job roles. Thus, OCB is believed to be able to reduce turnover rate in the organization effectively.

\section{Turnover Intention among Generation $\mathbf{Y}$}

In the literature review of turnover intention, Collin (2015) and fellow researchers defined turnover intention as voluntary and in-voluntary. Voluntary means employees voluntarily resign from their current job whereas involuntarily refers to organization's intention to initiate dismissal of the employees. Further on describing turnover intention, Simon, Muller and Hasselhorn (2010) described turnover intention as thought or intention to quit the job. This is supported by Tett and Meyer (1993) in elaborating turnover intention as the emphasis on the desire or deliberateness of an employee to leave the organization. In a research conducted by Yamazakia and Petchdee (2015), it was stated that the process of turnover intention is comprising three stages where firstly, the employees will start to have the thought of leaving the organization, subsequently they will begin to search for new job opportunities and finally they will plan to leave the organization. Thus, based on the above explanations, Windya (2008) and other researchers revealed that employees with high turnover intention will become less efficient and low in productivity. In explaining turnover intention of the generation Y employees, Queiri (2015) and fellow colleagues highlighted that Malaysia was among the countries in addressing the turnover issue as reported by various newspapers such as The New Strait Times, The Star and The Edge. Human Resource Managers in Malaysia have pointed out that the high turnover rate was stemming from generation $Y$ employees and this has resulted the organization to be highly alert on the issues that may become prevalent in the organization. This factor is crucial and able to affect the organization's functioning and success. Employee's turnover continues to be the pertinent issues to be mentioned in the organization's context (Queiri \& et al, 2015). Several surveys have shown that generation Y employees especially in the Asian Pacific region are generally reported to have the shortest length of service or job tenure compared with other generation in the work role (Queiri \& et al, 2015). As pointed out by Sheahan (2008), employees from generation $Y$ are reported to have only eighteen months of average length of service compared to others in the workforce which have 4 years of service averagely. Queiri (2015) and fellow colleagues primarily emphasized that with such a high job mobility among employees in generation $\mathrm{Y}$, it creates a negative impact towards different personnel involved, which highly impact towards the organizational effectiveness and functioning. Organizations face the issues in adjusting their employees work role and in dealing with their attitudes towards the work assigned. Most of the time, employers do not have the insight in understanding their employees' concerned issues and their personal problem in dealing with the work role. Employers mostly will look for results rather than the internal satisfaction of the employees. Employers generally ignored the intrinsic value and did not recognize the employees' intrinsic motivation in performing their jobs. It has become a phenomenon 
INTERNATIONAL JOURNAL OF ACADEMIC RESEARCH IN BUSINESS AND SOCIAL SCIENCES Vol. 8, No. 7, July 2018, E-ISSN: 2222-6990 @ 2018 HRMARS

that creates threatening environment towards the economic growth of the country in several ways (Queiri \& et al, 2015). Choong (2013) and fellow colleagues observed a trending in generation $Y$ that most of the them have migrated to the neighbouring countries like Singapore and Australia and approximately $62 \%$ of them have become an immigrant in other countries. Downe (2012) and fellow researchers examined this issue and highlighted that it has progressively become problematic in Malaysia as the country is facing shortage of manpower and talents. Queiri (2015) indirectly pointed that employees of generation $Y$ have different attitude and behavioural intentions in nature when dealing with different phenomenon. It was observed that generation $Y$ employees have different characteristics and preferences in performing certain work roles. Twenge and Campbell (2008) selectively reported that employees of generation $Y$ are more prompt to different aspirations and desires in their workplace which guide their behaviour intentions and attitudes. In short, retaining employees is perceived as the most difficult issue face by most organizations. Basically, employers failed to satisfy their employees' needs and wants. Employees tend to leave the organization when they do not have the sense of belongingness and commitment towards the organization. However, Somech and Drach-zahavy (2004) pointed out that individuals who perform beyond the role expectations were extensively attached to organizational citizenship behaviours. Podsakoff (2009) and fellow colleagues stated that organization may be beneficial by encouraging and supporting their employees in engaging in OCB, as it has been proven that OCB will boost productivity, reduce costs, and decrease turnover rate and absenteeism in an organization.

\section{Organizational Citizenship Behaviour (OCB)}

Organ (1988) described organizational citizenship behaviour as a voluntary act in nature. Most of the time, these behavioural intentions should be viewed as a personal choice in performing (as cited in Zhang, 2011). On the other hand, a study of Leephaijaroen (2014) defined organizational citizenship behaviour as a behaviour in individuals on their willingness in accepting additional work assignment which is not part of their job responsibilities. Their degree of preparedness is not depending on the external rewarding system but is purely from their intrinsic motivation. OCB could be categorized into five dimensions which are altruism, conscientiousness, courtesy, sportsmanship and civic virtue (Mahdiuon \& et al, 2010). Kerr, Godfrey-Smith and Feldman (2004) regarded altruism as a behaviour that will be beneficial to others but incurring personal cost on the performers. Organ (1991) defined altruism as the involvement of colleagues in helping their co-workers to deal with certain unusual duty in a specific circumstance or during the time which beyond one's expectations (as cited in MalekalketabKhiabani \& Abdizadeh, 2014). Sesardic (1999) mentioned that in defining the evolutionary of altruism concept, the behavioural effects and fitness plays a crucial role. If an individual behave in an increase of fitness, the individual will be categorized as behaving altruistically in the evolutionary sense (Sesardic, 1999). In a former psychological explanation on altruism, it has been defined as an individual who engaged in altruistic behaviour has an ultimate intention to gain interests of others at the cost of his own interest (Sesardic, 1999). Conscientiousness is regarded as one of the important elements in the Big Five taxonomy of personality traits. Roberts et al. (2009) defined the term conscientiousness as the tendency to react in certain ways in accordance to the situation. In other words, it means that individuals will be able to think, feel and behave in a consistent fashion across different point of time in a particular situation. However, Organ (1991) described that conscientiousness is the behaviour that goes beyond the specification of an organization such as job requirement that may not be recognized by anyone. It plays a major role in most of the social context like job performance, income, occupational attainment and leadership. In 
INTERNATIONAL JOURNAL OF ACADEMIC RESEARCH IN BUSINESS AND SOCIAL SCIENCES Vol. 8, No. 7, July 2018, E-ISSN: 2222-6990 @ 2018 HRMARS

such, conscientiousness is highly related a person's responsibility in reacting and the intention in engaging with his works. In return, it promotes work efficiency (MalekalketabKhiabani \& Abdizadeh, 2014) and it conveys benefits to the organization and reduce turnover rate (Organ, 1997). Modassir and Singh (2008) stated that courtesy refers to the manner in treating others with mutual respect, giving proper information to others, and distributing information and details to others who required. William and Anderson (1991) suggested that courtesy and altruism were found to have a close positive relationship to each other and it has been categorized as an individual-directed behaviour which highly depends on personal intention in performing the behaviour. Most of the time, employees who engaged in courtesy behaviour will be humble in learning and asking for clarification and guiding others who are in need of help. Courtesy behaviour may create a mutual respect and a more understanding environment which enable well-being and better teamwork in the organization. For sportsmanship, Modassir and Singh (2008) described that it is a behaviour of citizenship posturing tolerance towards the unavoidable circumstances or work, without any further complaints. Previous research of Williams and Anderson (1991) stated that sportsmanship, civic virtue and conscientiousness create a positive alignment with each other, and the three dimensions have been categorized as the organizational-directed behaviour rather than individually oriented. As such, sportsmanship will be more prone towards internal volunteerism in performing task rather than being forced by the environmental factors. Individuals may perform based on their personal interests and react according to the situational factors. Redman and Snape (2005) referred the behaviour of civic virtue as the display of responsibility concerning issues for the individual's well-being and the reputation of the organization. Borman (2001) and researchers concurred that civic virtue is highly related to the behaviour of individuals which shows they are responsible and concern about the reputation and image of the organization. They are willing to participate in any event of the organization. A study of Coole (2003) gave evident explanations that civic virtue is more restricted and strictly correlated with organizational effectiveness. This means that the higher the effectiveness of the organization, the higher the possibility of the behaviour to be emerged. In relation to OCB engagement and turnover intention, Zhang (2011) regarded OCB as a term where employees perform positive behaviour to support co-workers in the organization. Employees who engaged in OCB were often known to be the one who willingly perform without expecting rewards and return, they spent plenty of efforts to make sure that things were done orderly and satisfied with what they had performed (Zhang, 2011). Zhang (2011) also stated that if organizations encourage their employees to engage in $O C B$, in return, it will increase productivity, efficiency, customer satisfaction, reduce turnover rate, cost and absenteeism in the workplace. Organ, Podsakoff and Mackenzie (2006) suggested that organizations may assist in promoting and providing a conducive environment for employees in displaying OCB. Organizations may boost their employees' motivation by supporting them in OCB engagement (as cited in Zhang, 2011). Organ (2006) and fellow researchers valued the suggestions that OCB may enhance productivity, free up resources, enhance group cohesiveness, attract and retain good employees, create better social communication and reduce turnover intention (as cited in Zhang, 2011). Therefore, based on the above discussion, the following hypothesis are proposed in this study:

$\mathrm{H} 1$ : Altruism has a negative relationship with turnover intention.

$\mathrm{H}$ 2: Conscientiousness has a negative relationship with turnover intention.

H3: Courtesy has a negative relationship with turnover intention.

$\mathrm{H} 4$ : Sportsmanship has a negative relationship with turnover intention. 
INTERNATIONAL JOURNAL OF ACADEMIC RESEARCH IN BUSINESS AND SOCIAL SCIENCES

Vol. 8, No. 7, July 2018, E-ISSN: 2222-6990 @ 2018 HRMARS

H5: Civic Virtue has a negative relationship with turnover intention.

\section{Methodology \\ Participants}

The targeted participants were generation $\mathrm{Y}$ in Malaysia. 384 respondents of the age range from 17 to 36, and currently engaging in the workforce were selected to participate in the survey. From the responses the researchers received, 214 were female respondents and 170 were males. Majority of the respondents were aged from 22-26 (135, 35.2\%). Those aged between 27-31 years old constituted 132 of the total respondents, representing $34.4 \%$ of the samples. As for the other age groups, those aged from 17-21 were 43 respondents, aged 22-26 were 135 respondents and 74 respondents were aged from 32-36. For length of service, most of the respondents were having 3-5 years of experience (136), followed by above 5 years (121), 1-2 years (79) and below 1 year (48). Majority of the respondents were junior executives (110, 28.6\%), followed by executives (87, $22.7 \%)$, senior executives $(79,20.6 \%)$, managers $(67,17.4 \%)$ and senior managers $(41,10.7 \%)$. For the level of education, 183 respondents (47.7\%) possessed a degree and 86 respondents (22.4\%) were with a diploma. This is followed by 65 respondents with SPM certificate (16.9\%), Masters $(47,12.2 \%)$ and doctorate degree $(3,0.8 \%)$. g 1-2 years of experience.

\section{Method and Instruments}

This study is quantitative in nature which used survey as the research method. The sampling method was referred to the Krejcie and Morgan (1970) table whereby if the population is more than 1 million, the sampling size required would be 384 respondents. The measures of organizational citizenship behaviour were adapted from Fox and Spector (2011). Measures for turnover intention were adopted from Lee (2008). Likert scale was used to measure all the study variables. The scale was anchored by 1 (Strongly disagree), 2 (Disagree), 3 (Neutral), 4 (Agree) and 5 (Strongly agree).

\section{Data Analysis}

Data analysis in the present study was conducted by using Statistical Package for Social Science (SPSS). Factor analysis was selected to test the validity of the variables and to assess how well the measures represent the concept being measured (Sekaran and Bougie, 2010). Reliability test was employed to test the internal consistency of the study variables. Separately, correlation analysis and multiple regression analysis was used to examine the relationship between organizational citizenship behaviour (OCB) and turnover intention.

\section{Results}

\section{Factor Analysis}

\section{Organizational Citizenship Behaviour (OCB)}

The data received from the respondents were tested using factor analysis to ensure its validity. Table 1 represents the results of factor analysis. The value of Kaiser-Meyer-Olkin for Measuring of Sampling Adequacy (KMO/MSA) was 0.843 for OCB. According to Widyastuti, Maisaroh and Parimita (2013), $\mathrm{KMO} / \mathrm{MSA}$ is used to measure the adequacy of the sample in comparing with the degree of the determined correlation coefficients with partial coefficient. In assessing the value of KMO/ MSA, if the calculated value is greater than 0.5 , it indicates that the factor analysis is ready to proceed further; but on the other hand, if the value shown is less than 0.5 , then revision shall be made (Widyastuti, Maisaroh \& Paimita, 2013). The Barlett's Test of Sphericity was found to be significant at the 0.000 
INTERNATIONAL JOURNAL OF ACADEMIC RESEARCH IN BUSINESS AND SOCIAL SCIENCES Vol. 8, No. 7, July 2018, E-ISSN: 2222-6990 @ 2018 HRMARS

level, thus supported the factorability of the correlation matrix. The principal component analysis (PCA) with varimax rotation extracted three (3) components from the independent variables after cross loadings were deleted and factor loading of 0.35 and below were discarded. The rotated factors captured a total of $56.65 \%$ of the variance in which component 1 contributes $36.621 \%$, followed by component 2 at 10.963\%, and component 3 at 9.065\%. Drawing on the factor analysis results (see Table 2), items that loaded on component 1 (5 items) were labelled as altruism, component 2 (4 items) was named sportsmanship and component 3 (3 items) was classified as courtesy. However, conscientiousness and civic virtue were eliminated.

Table 1: KMO and Bartlett's Test of IVs.

\begin{tabular}{llr}
\hline \multicolumn{3}{c}{ KMO and Bartlett's Test } \\
\hline Kaiser-Meyer-Olkin Measure of Sampling Adequacy. & 0.843 \\
\hline Bartlett's Test of Sphericity & $\begin{array}{l}\text { Approx. } \\
\text { Chi-Square }\end{array}$ & 1475.836 \\
\cline { 2 - 3 } & df & 66 \\
\cline { 2 - 3 } & Sig. & 0.000 \\
\hline
\end{tabular}

Table 2: Factor Analysis for Organizational Citizenship Behaviour

\begin{tabular}{cccc}
\hline & \multicolumn{3}{c}{ Rotated Component Matrix } \\
& \multicolumn{3}{c}{ Component } \\
\cline { 2 - 4 } & 0.768 & 2 & \\
\hline OCB2 & 0.843 & & \\
OCB3 & 0.784 & & \\
OCB4 & 0.747 & & \\
OCB5 & 0.734 & & 0.814 \\
OCB6 & & & 0.723 \\
OCB7 & & & 0.526 \\
OCB8 & & 0.553 & \\
OCB9 & & 0.684 & \\
OCB12 & & 0.600 & \\
OCB13 & & 0.642 & 1.088 \\
OCB14 & 4.395 & 1.316 & \\
OCB19 & & & 9.065 \\
Eigenvalues & 36.621 & 10.963 & 56.650 \\
Percentage of & 36.621 & 47.585 & 0.688 \\
Common Variance & & & \\
Cumulative \% & 0.821 & 0.557 & \\
Reliability & & & \\
Coefficient $(\alpha)$ & & & \\
\hline
\end{tabular}


INTERNATIONAL JOURNAL OF ACADEMIC RESEARCH IN BUSINESS AND SOCIAL SCIENCES Vol. 8, No. 7, July 2018, E-ISSN: 2222-6990 @ 2018 HRMARS

\section{Turnover Intention}

Table 3 shows the KMO and Barlett's Test for the dependent variable, turnover intention. The value of $\mathrm{KMO} / \mathrm{MSA}$ was 0.824 . It indicates that the variable is great for factor analysis. The Barlett's Test of Sphericity was found to be significant at the 0.000 level, thus supported the factorability of the correlation matrix. The principal component analysis (PCA) extracted 5 items that captured a total variance of $58.896 \%$ with an Eigenvalue of 2.945 . The values of factor loading for turnover intention were in the range of 0.598 to 0.887 , whereas there is none of the items were discarded due to cross loading. All the 5 items were loaded on a single factor (see Table 4).

Table 3: KMO and Barlett's Test Turnover Intention.

\begin{tabular}{ccc}
\hline \multicolumn{3}{c}{ KMO and Bartlett's Test } \\
\hline Kaiser-Meyer-Olkin Measure of Sampling Adequacy. & 0.824 \\
\hline Bartlett's Test of Sphericity & Approx. Chi-Square & 732.986 \\
\hline & df & 10.000 \\
\hline
\end{tabular}

Table 4: Factor Analysis for Turnover Intention.

\begin{tabular}{cc}
\hline \multicolumn{2}{c}{ Rotated Component Matrix } \\
\cline { 2 - 2 } & Component \\
\hline TI1 & 1 \\
TI2 & 0.801 \\
TI3 & 0.865 \\
TI4 & 0.598 \\
TI5 & 0.887 \\
Eigenvalues & 0.641 \\
\hline Percentage of Common Variance \% & 2.945 \\
Cumulative \% & 58.896 \\
Reliability Coefficient $(\alpha)$ & 58.896 \\
\end{tabular}

\section{Reliability Test}

The reliability tests were performed by using SPSS software analysis. The reliability of the variables was based on the value of Cronbach's Alpha's. According to Tavakol and Dennick (2011), the acceptable value of Cronbach's Alpha shall be ranging from 0.70 to 0.95 . The reliability coefficient (Cronbach's Alpha) for the independent variables namely altruism, sportsmanship and courtesy was rated $0.821,0.557$ and 0.688 respectively. Cronbach's Alpha value for the dependent variable, turnover intention was 0.867 . Therefore, the dimension of sportsmanship $(\alpha=0.557)$ was discarded whereas altruism and courtesy were deemed reliable and consistent throughout the study.

\section{Correlational Analysis}

Pearson correlation analysis was employed to examine the correlation between turnover intention and the independent variables namely altruism and courtesy respectively. The results in Table 5 were indicating correlations between altruism and courtesy $(r=0.621, p<0.01)$. However, there was no 
INTERNATIONAL JOURNAL OF ACADEMIC RESEARCH IN BUSINESS AND SOCIAL SCIENCES

Vol. 8, No. 7, July 2018, E-ISSN: 2222-6990 @ 2018 HRMARS

correlation found between altruism and turnover intention, courtesy and turnover intension. Multiple regression analysis will be conducted to further examine the relationship between the variables.

Table 5: Correlations Analysis for the Study Variables.

\begin{tabular}{cccc}
\hline & Altruism & Courtesy & $\begin{array}{c}\text { Turnover } \\
\text { Intention }\end{array}$ \\
\hline Altruism & 1 & & \\
\hline Courtesy & $.621^{* *}$ & 1 & \\
\hline Turnover Intention & -.080 & -.010 & 1 \\
\hline$* *$ Correlation is significant at the 0.01 level (2-tailed).
\end{tabular}

\section{Regression Analysis}

In Table 6, the standardized coefficient for altruism $(\beta=-0.140, p<0.05)$ was found to be significantly and negatively related to turnover intention. However, courtesy was discovered to be not significantly associated with turnover intention. Therefore, it can be concluded that only $\mathrm{H} 1$ was accepted, which indicates altruism has a negative relationship with turnover intention.

Table 6: Multiple Regression Analysis

\begin{tabular}{|c|c|c|c|c|c|}
\hline \multicolumn{6}{|c|}{ Coefficients } \\
\hline \multirow{3}{*}{ Model } & $\begin{array}{r}\text { Unstan } \\
\text { Coef } \\
\end{array}$ & $\begin{array}{l}\text { rdized } \\
\text { ients }\end{array}$ & $\begin{array}{c}\text { Standardized } \\
\text { Coefficients }\end{array}$ & \multirow[b]{3}{*}{$\mathrm{t}$} & \multirow[b]{3}{*}{ Sig } \\
\hline & \multicolumn{3}{|c|}{ Std } & & \\
\hline & $\mathrm{B}$ & Error & Beta & & \\
\hline (Constant) & 3.399 & .344 & & 9.878 & .000 \\
\hline Altruism & -.199 & .094 & $-.140 *$ & -2.108 & .036 \\
\hline Courtesy & .065 & .089 & .048 & .730 & .466 \\
\hline
\end{tabular}

a. Dependent Variable: Turnover Intention. $\quad *$ significant at the level 0.05.

\section{Discussion and Conclusion}

The objective of the research is to examine the influence of Organization Citizenship Behaviour towards turnover intention. In the findings of this research, it was found that the dimensions of OCB, namely conscientiousness and civic virtue were eliminated during factor analysis where the factor loadings were below 0.35 and factor configuration was not exist. Further examination of the extracted factors (altruism, sportsmanship and courtesy), it was discovered that the reliability of sportsmanship ( $\alpha=0.557$ ) did not surpass the minimum level of Cronbach's Alpha. However, altruism $(\alpha=0.821)$ and courtesy $(\alpha=0.688)$ were retained for further analysis with the dependent variable, turnover intention ( $\alpha=0.867$ ). The multiple regression analysis revealed that altruism was significant and negatively related to turnover intention $(\beta=-0.14, p<0.05)$. This finding is consistent with previous studies by Chen et al. (1998). Altruism is the OCB dimension that fosters the involvement of colleagues in helping each other to deal with problems and unusual duties which beyond one's expectations. According to Chen et al. (1998), employees who exhibited altruism behaviour were unlikely to leave the organization. This is further supported by the Cognitive Consistency Theory 
INTERNATIONAL JOURNAL OF ACADEMIC RESEARCH IN BUSINESS AND SOCIAL SCIENCES Vol. 8, No. 7, July 2018, E-ISSN: 2222-6990 @ 2018 HRMARS

where it stated that individuals try to maintain agreement between their behaviours and attitudes. There is a tendency for individuals to seek consistency among their cognitions. Behaviour like altruism would continuously shape their attitude to retain in the organization and report a low turnover intention. In addition, Batson (1991) described that altruism has a close linkage with the feeling of empathy. Empathy is regarded as putting oneself in other's shoes and able to feel the emotion and experience of how other people feel and thus they can react in accordance to the situation, behave wisely and remain in the organization. On the other hand, courtesy was found not significantly related to turnover intention. The plausible reason to explain this finding is that courtesy behaviour may not associate well with the norm and culture of their workplace, particularly in work involvement and career advancement. For example, Wagner and Rush (2000) stated that younger employees have less need for affiliation whereby Kuehn and Al-Busaidi (2002) reported that younger workers have lower level of courtesy than older workers. This research has successfully conducted and provided indispensable information in explaining the influence of organizational citizenship behaviour towards turnover intention of generation Y. It has given a beneficial insight especially for Human Resource Managers to recruit employees with specific organizational citizenship behaviour that could effectively reduce turnover intention and ensure a low turnover rate in the organization. For future study, it is suggested that researchers could specifically target the study towards a specific sector to identify desired organizational citizenship behaviour in understanding the employee's turnover intention.

\section{Acknowledgements}

The authors would like to thank the Malaysian Ministry of Higher Education and Universiti Teknologi Malaysia (GUP-Vot: 14J81) for providing financial support to publish this paper.

\section{References}

Borman, W. C., Penner, Louise. A., Allen, Tammy D., \& Motowidlo. Stephan J. (2001). Personality predictors of citizenship performance. International Journal of Selection and Assessment, 9(12), 52-69.

Chen, X.P., Hui, C., \& Sego, D.J. (1998). The role of organizational citizenship behaviour in turnover: conceptualization and preliminary tests of key hypothesis. Journal of Applied Psychology, 3(6), 922-931.

Choong, Y. O., Keh, C. G., Tan, Y. T., \& Lim, Y. H. (2013). Propensity to work abroad amongst generation-Y working adults in malaysia (pp. 695-705). Penang, Malaysia, World Conferences.

Collins, S., Collins, S., McKinnies, R. C. \& Matthews, E. P. (2015). A mini-study of employee turnover in US Hospitals. Retrieved from https://pdfs.semanticscholar.org/02d9/f942a024c1c23f00042d54575237cde5c5a4.pdf

Coole, D. R. (2003). The effects of citizenship performance, task performance, and rating format on performance judgments. University of South Florida.

Downe, A., Loke, S. P., Ho, J., \& Taiwo, A. (2012). Corporate talent needs and availability in Malaysian service industry. International Journal of Business and Management, 7(2), 224-235. http://dx.doi.org/10.5539/ijbm.v7n2p224

DW, O. (1991). The applied psychology of work behaviours: A book of reading. USA: Richard D. Irwin, Inc. 
INTERNATIONAL JOURNAL OF ACADEMIC RESEARCH IN BUSINESS AND SOCIAL SCIENCES

Vol. 8, No. 7, July 2018, E-ISSN: 2222-6990 @ 2018 HRMARS

Fox, S., \& Spector, P. E. (2011). Organization citizenship behaviour checklist (OCB-C). Retrieved from https://view.officeapps.live.com/op/view.aspx?src=http://shell.cas.usf.edu/ pspector/scales/ OCB-Cdevelopment.doc

Kerr, B., Godfrey-Smith, P. \& Feldman, M. W. (2004). What is altruism? Trends in Ecology and Evolution, 19(3). DOI: https://doi.org/10.1016/j.tree.2003.10.004

Krejcie, R. V., \& Morgan, D. W. (1970). Determining sample size for research activities. Educational and psychological measurement, 30, 607-610. Retrieved from https://home.kku.ac.th/sompong/guest_speaker/KrejcieandMorgan_article.pdf

Kuehn, K.W., \& Al-Busaidi, Y. (2002), Citizenship behaviour in a non-western context: an examination of the role of satisfaction, commitment and job characteristics on self- reported organizational citizenship behaviour. International Journal of Commerce \& Management, 12(2), 107-125.

Lee, W. J. (2008). A pilot survey of turnover intention and its determinants among adult probation line officers in Texas. Retrieved form https://view.officeapps.live.com/op/view.aspx?src=http://taylorcscd.org/pac/Executive\%20S ummary_Won-Jae\%20Lee.doc

Leephaijaroen, S. (2014). Effects of the big-five personality traits and organizational commitments on organizational citizenship behaviour of support staff at ubon ratchathani Rajabhat university, Thailand. Kasetsart Journal of Social Sciences, 37(2). DOI: 10.1016/j.kjss.2015.03.002

Mahdiuon, R., Ghahramani, M., \& Sharif, A. R. (2010). Explanation of organizational citizenship behaviour with personality. Procedia Social and Behavioural Sciences, 5(2010), 178-184. DOI: 10.1016/j.sbspro.2010.07.069

MalekalketabKhiabani, M., \& Abdizadeh, M. (2014). Identifying the key factors of organizational citizenship behaviour in the healthcare industry: Iran perspective. International Journal of Research in Management, 4(4). from https://rspublication.com/ijrm/2014/july14/9.pdf

Modassir, A., \& Singh, T. (2008). Relationship of emotional intelligence with transformational leadership and organizational citizenship behaviour. International journal of leadership studies, $4(1), 3-21$

Organ, D. W. (1988). Organizational citizenship behaviour: The good soldier syndrome. USA: D.C. Heath and Company. Organ, D. W. (1997). Organizational citizenship behaviour: It's construct clean-up time. Human Performance, 10(2), 85-97. doi: 10.1207/s15327043hup1002_2

Organ, D. W. (1997). Organizational citizenship behaviour: It's construct clean-up time. Human Performance, 10(2), 85-97. doi: 10.1207/s15327043hup1002_2

Organ, D. W. (2014). Organizational citizenship behaviour: it's construct clean-up time. Human performance, 10(2), 85-97. DOI: 10.1207/s15327043hup1002_2

Podsakoff, N. P., Whiting, S. W., Podsakoff, P. M., \& Blume, B. D. (2009). Individual- and organizational-level consequences of organizational citizenship behaviours: A meta-analysis. Journal of Applied Psychology, 94(1), 122-141. doi: 10.1037/a0013079

Queiri, A., Wan Yusoff, W. F., \& Dwaikat, N. (2015). Explaining generation Y employees' turnover in Malaysian context. Asian Social Science, 11(10). doi:10.5539/ass.v11n10p126

Redman, T., \& Snape, E. (2005). I to Wed: The role of consciousness transformation in compassion and Altruism. Journal of Management Studies, 42(2), 2200-2380.

Roberts, B. W., Jackson, J. J., Fayard, J. V., Edmonds, G., \& Meints, J. (2009). Conscientiousness. Handbook of individual differences in social behaviour (369-381). New York, NY, US: Guilford Press. Retrieved from http://psycnet.apa.org/record/2009-12071-025 
INTERNATIONAL JOURNAL OF ACADEMIC RESEARCH IN BUSINESS AND SOCIAL SCIENCES

Vol. 8, No. 7, July 2018, E-ISSN: 2222-6990 @ 2018 HRMARS

Sekaran, U., \& Bougie, R. (2010). Research methods for business: A skill-building approach (5th ed.). Haddington: John Wiley \& Sons.

Sesardic, N. (1999). Altruism. Brit. J. Phil. Sci., 50, 457-466. Retrieved from http://www.In.edu.hk/philoso/staff/sesardic/Altruism.pdf

Sheahan, P. (2008). Generation-Y In Asia. Sydney: The University of Sydney.

Simon, M., Muller, B. H., \& Hasselhorn, H. M. (2010). Leaving the organization or the profession - a multilevel analysis of nurses' intentions. Journal of Advanced Nursing, 66(3), 616-626. Retrieved from https://core.ac.uk/download/pdf/9619.pdf

Somech, A., \& Drach-Zahavy, A. (2004). Exploring organizational citizenship behavior from an organizational perspective: the relationship between organizational learning and organizational citizenship behavior. Journal of Occupational and Organizational Psychology, 77(3), 281-298.

Tavakol, M. \& Dennick, R. (2011). Making sense of Cronbach's alpha. International Journal of Medical Education, 2, 53-55. DOI: 10.5116/ijme.4dfb.8dfd

Tett, R. P., \& Meyer, J. P. (1993). Job satisfaction, organization commitment, turnover intention, and turnover: path analyses based on meta-analytic findings. Personnel Psychology, 46(2), 259-293. Retrieved from http://dx.doi.org/10.1111/j.1744-6570.1993.tb00874.x

Twenge, J. M., \& Campbell, S. M. (2008). Generational differences in psychological traits and their impact on the workplace. Journal of Managerial Psychology, 23(8), 862-877. Retrieved from http://www-

personal.umich.edu/ prestos/Downloads/DC/pdfs/Redman_Sept29_TwengeCampbell2008.pdf

Wagner, S.L. \& Rush, M.C. (2000), Altruistic organizational citizenship behaviour: context, disposition, and age. Journal of Social Psychology, 140(3), 379-392.

Windya, N. (2008). 13 Jurus Jitu Sukses di Dunia Kerja karya. Jakarta: Daras Books.

Widyastuti, U., \& Parimita, W. (2013). Analysis of factors in quality of work life faculty of economics state university of Jakarta. Proceedings of 23rd International Business Research Conference. Retrieved from https://wbiworldconpro.com/uploads/melbourne-conference-2013november/management/1384595813_423-Umi.pdf

Williams, L. J. \& Anderson, S. E. (1991). Job satisfaction and organizational commitment as predictors of organizational citizenship and in-role behaviours. Journal of management, 17(3), 601-617.

Yamazakia, Y. \& Petchdee, S. (2015). Turnover intention, organizational commitment, and specific job satisfaction among production employees in Thailand. Journal of Business and Management, 4(4), 22-38. DOI: 10.12735/jbm.v4i4p22.

Zhang, D. (2011). Organizational citizenship behaviour. Retrieved from https://cdn.auckland.ac.nz/assets/psych/about/our-people/documents/Deww\%20Zhang\%20\%200rganisational\%20Citizenship\%20Behaviour\%20-\%20White\%20Paper.pdf 